\title{
PENGARUH PENDIDIKAN DAN PENGALAMAN PADA PENDAPATAN RUMAH TANGGA DI INDONESIA
}

\author{
Endang Taufiqurahman \\ endangtaufiq@yahoo.co.id \\ Departemen Ilmu Ekonomi FEB Universitas Padjadjaran Bandung
}

\begin{abstract}
This research analyse influence of education, job experience, level of parent education and amount of sibling to wages and family income at Indonesian family. Hereafter this research analyse how total family income to measure education and experience role give same explanation than utilizes wage measure. This research will utilize model Mincer Wage Regression on Indonesian family. Analisis's method utilizes IV (Instrumental Variable). The data will be used is panel data from IFLS (Indonesian Family Life Survey) which is IFLS 3 years 2000 and IFLS 4 years 2007. Result observation was point out that amount of sibling not significant influence to average education of employment at family, meanwhile parent education is influence signifikan to average education of employment at family. Hereafter average education and experience of employment is significant influence to income and wage at Indonesian family. Then wages measure point out stronger influence than by use of measure total income to measure how education and experience influence to family income at Indonesian.
\end{abstract}

Keywords: experience, education, instrumental variable (IV), parent education, sibling

\begin{abstract}
ABSTRAK
Penelitian ini menganalisa pengaruh pendidikan, pengalaman kerja, tingkat pendidikan orang tua dan jumlah anak kandung terhadap upah dan pendapatan rumah tangga di Indonesia. Selanjutnya mengetahui apakah penggunaan ukuran total pendapatan rumah tangga untuk mengukur peran pendidikan dan pengalaman memberikan penjelasan yang sama dibandingkan menggunakan ukuran upah. Penelitian ini akan menggunakan model Mincer Wage Regression pada tingkat rumah tangga Indonesia. Metode analisis menggunakan IV (Instrumental Variabel). Data yang akan dipergunakan adalah data panel yang bersumber dari IFLS (Indonesian Family Life Survey) yaitu IFLS-3 tahun 2000 dan IFLS-4 tahun 2007. Hasil penelitian menunjukkan bahwa jumlah anak kandung tidak berpengaruh secara signifikan terhadap rata-rata pendidikan pekerja di rumah tangga, sedangkan tingkat pendidikan orang tua menunjukkan pengaruh yang signifikan terhadap rata-rata pendidikan pekerja di rumah tangga. Selanjutnya rata-rata pendidikan dan pengalaman pekerja di rumah tangga berpengaruh signifikan terhadap pendapatan maupun upah rumah tangga di Indonesia. Kemudian ukuran upah menunjukan pengaruh yang lebih kuat dibandingkan dengan menggunakan ukuran total pendapatan dalam mengukur pengaruh pendidikan dan pengalaman terhadap pendapatan rumah tangga di Indonesia.
\end{abstract}

Kata kunci : pengalaman, pendidikan, instrumental variabel (IV), pendidikan orang tua, anak kandung

\section{PENDAHULUAN}

Kualitas sumber daya manusia Indonesia masih relatif rendah. Menurut laporan HDR (Human Development Report) yang diterbitkan oleh UNDP (United Nations Development Programme) pada tahun 2011 menunjukkan bahwa peringkat SDM Indonesia masih berada pada posisi 124 dari 187 negara di dunia. Peringkat tersebut lebih rendah dibandingkan negara Asia Tenggara lainnya seperti Malaysia di peringkat ke-61, Thailand di peringkat ke-103, dan Philipina di peringkat ke-112 (Tabel 1). Posisi Indonesia pada peringkat ke-124 tersebut menjadikannya masih berada pada kelompok negara kelompok pembangunan manusia 
menengah (medium human development). Kelompok pembangunan manusia menengah adalah untuk negara pada peringkat 95-141, sedangkan peringkat 48-94 adalah kelompok pembangunan manusia tinggi (high human development), peringkat 1-47 kelompok pembangunan manusia sangat tinggi (very high human development), sedangkan kelompok terbawah 142-187 adalah kelompok pembangunan manusia rendah (low human development) (UNDP, 2012). Namun bila diukur secara individual peringkat SDM Indonesia menurut HDR selama kurun waktu 1980-2011 menunjukkan kecenderungan yang meningkat. Peringkat
SDM Indonesia menurut HDR tahun 1980 adalah 0,423, kemudian tahun 1990 menjadi 0,481 , tahun 2000 menjadi 0,543 , dan tahun 2011 menjadi 0,617, tetapi kenaikan tersebut masih lebih rendah bila dibandingkan pencapaian negara-negara lain. Untuk diketahui bahwa ukuran kualitas SDM dalam HDR adalah dihitung berdasarkan beberapa kriteria yaitu: pendapatan perkapita, pendidikan, kesehatan, tingkat harapan hidup, pertumbuhan ekonomi, dan kesetaraan gender. Relatif rendahnya peringkat Indonesia pada laporan HDR tersebut menunjukkan bahwa upaya pembangunan manusia di Indonesia masih belum optimal.

Tabel 1

Peringkat HDI pada Empat Negara Asia Tenggara Tahun 2011

\begin{tabular}{rlcccccc}
\hline \hline $\begin{array}{c}\text { Peringkat } \\
\text { HDI }\end{array}$ & Negara & $\begin{array}{c}\text { Nilai } \\
\text { HDI }\end{array}$ & $\begin{array}{c}\text { Tingkat } \\
\text { Harapan } \\
\text { Hidup } \\
\text { (tahun) }\end{array}$ & $\begin{array}{c}\text { Rata-rata } \\
\text { Tahun } \\
\text { Sekolah } \\
\text { (tahun) }\end{array}$ & $\begin{array}{c}\text { Ekspektasi } \\
\text { Tahun } \\
\text { Sekolah } \\
\text { (tahun) }\end{array}$ & $\begin{array}{c}\text { Gross } \\
\text { National } \\
\text { Income } \\
\text { perkapita } \\
\text { (\$/tahun) }\end{array}$ & $\begin{array}{c}\text { Nilai } \\
\text { Non- } \\
\text { Income } \\
\text { HDI }\end{array}$ \\
\hline 61 & Malaysia & 0,761 & 74,2 & 9,5 & 12,6 & 13.685 & 0,790 \\
103 & Thailand & 0,682 & 74,1 & 6,6 & 12,3 & 7.694 & 0,714 \\
112 & Philipina & 0,644 & 68,7 & 8,9 & 11,9 & 3.478 & 0,725 \\
124 & Indonesia & 0,617 & 69,4 & 5,8 & 13,2 & 3.716 & 0,674 \\
\hline
\end{tabular}

Sumber : UNDP, 2011

Tujuan utama dari penelitian ini adalah untuk mengetahui pengaruh dari pendidikan dan pengalaman terhadap pendapatan upah rumah tangga. Terdapat beberapa permasalahan yang akan dicari jawabannya dalam penelitian ini, yaitu: (1) Bagaimana pengaruh pendidikan pekerja, pengalaman pekerja, pendidikan orang tua dan jumlah anak kandung terhadap pendapatan rumah tangga Indonesia?, (2) Apakah penggunaan ukuran total pendapatan rumah tangga untuk mengukur peran pendidikan dan pengalaman memberikan penjelasan yang sama dibandingkan menggunakan ukuran upah untuk masyarakat Indonesia?, (3) Apakah penggunaan metoda IV (Instrumental Variabel) dengan instrumen jumlah anak kandung (sibling) terhadap pendidikan akan lebih mampu menjelaskan pengaruhnya terhadap perubahan pendapatan atau upah dibandingkan menggunakan instrumen tingkat pendidikan orang tua (EducHead) pada model Mincer Wage Regression pada level rumah tangga Indonesia?.

Penelitian ini akan menggunakan data panel tingkat (level) rumah tangga (tingkat mikro). Model yang akan digunakan dalam penelitian ini adalah model regresi upah dari Mincer (Mincer wage regession), sedangkan metoda analisis yang akan dipergunakan adalah metoda IV (Instrumental Variabel). Penggunaan model Mincer didasarkan pada pertimbangan: (1) Model tersebut menjelaskan hubungan antara pendidikan dan pengalaman kerja terhadap pendapatan, (2) Model tersebut banyak digunakan 
dalam berbagai penelitian tentang topik pendidikan di berbagai negara, (3) Model tersebut telah dikembangkan cukup lama sejak di perkenalkan oleh Mincer tahun 1958.

\section{TINJAUAN TEORETIS}

Dalam bahasa yang ringkas, Becker (1964) mendefinisikan modal manusia (human capital) sebagai seperangkat kemampuan (abilities), kecakapan (capabilities) dan pengetahuan (knowledge) yang diperlukan untuk bekerja. Semua karakterisik kemampuan tersebut diperoleh melalui belajar (study), pelatihan (training) dan pengalaman (experience). Becker mengidentifikasi fakta yang biasanya terjadi (stylized facts) sebagai dasar dari teori yang dibangunnya, bahwa: (1) Pendapatan individu dari bekerja akan semakin menurun sejalan dengan bertambahnya usia. (2) Peningkatan dalam penerimaan berkorelasi positif dengan peningkatan dalam keterampilan. (3) Tingkat pengangguran memiliki hubungan yang negatif dengan tingkat keterampilan, artinya jumlah pengangguran akan cenderung menurun bila tingkat keterampilan meningkat. (4) Perusahaan yang berlokasi di Negara berkembang lebih berperilaku paternalistik terhadap pekerja, sedangkan perilaku perusahaan di negara maju cenderung tidak berperilaku paternalistik, (5) Orang muda lebih memiliki mobilitas kerja yang tinggi dibandingkan yang lebih tua, dan mereka juga cenderung memperoleh pendidikan lebih baik terutama melalui pelatihan kerja (on-the-job-training). (6) Fungsi distribusi penerimaan adalah menceng positif (positively skewed) terutama diantara pekerja kualitas tinggi, artinya bahwa ratarata pendapatan yang lebih tinggi didapatkan oleh kelompok pekerja kualitas tinggi. (7) Kuantitas pendidikan dan tipe lainnya dari pelatihan akan diperoleh lebih banyak oleh yang memiliki kelebihan akses dibanding yang lainnya. (8) Pada prakteknya, investasi pada modal manusia memiliki kecenderungan impulsif (menuruti kata hati) dan lebih banyak salah di- bandingkan investasi pada modal fisik, artinya bahwa pengembangan SDM sering tidak selalui sesuai dengan kebutuhan dan lapangan kerja. Kesalahan tersebut banyak terjadi terutama di negara berkembang. Selanjutnya definisi modal manusia (human capital) menurut, OECD (Organisation for Economic Co-operation and Development, 2001) adalah: "The knowledge, skills, competencies and attributes embodied in individuals that facilitate the creation of personal, social and economic well-being" (Pengetahuan, keterampilan, kompetensi dan berbagai atribut termasuk potensi yang terdapat didalam diri individu yang mampu memfasilitasi kreasi secara personal, sosial dan kesejahteraan/kebaikan ekonomi).

Beberapa hasil penelitian yang telah membuktikan pentingnya peran beberapa komponen dari modal manusia terhadap pendapatan rumah tangga, diantaranya: tenaga kerja, pengalaman, pendidikan anggota keluarga berpengaruh positif terhadap pendapatan rumah tangga, sedangkan jumlah anggota keluarga berpengaruh negatif terhadap pendapatan rumah tangga (Xin dan $\mathrm{Wu}, 1998)$, tingkat pendidikan anggota keluarga berpengaruh positif terhadap pendapatan rumah tangga (Ravallion dan Wodon, 2000), tingkat pendidikan anggota keluarga, latar belakang pendidikan orang tua berpengaruh positif terhadap pendapatan rumah tangga (Fafchamps dan Quisumbing, 1999), jumlah anggota keluarga yang bekerja, tingkat pendidikan berpengaruh positif terhadap pendapatan rumah tangga (Creamer, 1961), jumlah pekerja wanita pada keluarga berpengaruh positif terhadap pendapatan rumah tangga (Ding at al., 2009), jumlah anggota keluarga berpengaruh negatif terhadap pendapatan rumah tangga, siapa kepala rumah tangga (ayah/ $\mathrm{ibu}$ ) berpengaruh terhadap pendapatan rumah tangga (Greif, 2006), komposisi usia anggota keluarga bila dominan pada usia produktif, maka berpengaruh positif terhadap pendapatan rumah tangga (Ravallion dan Wodon, 2000), komposisi usia anggota keluarga bila dominan pada usia produktif, 
maka berpengaruh positif terhadap pendapatan rumah tangga, jumlah anggota keluarga berpengaruh positif terhadap pendapatan rumah tangga, status pernikahan berpengaruh terhadap pendapatan rumah tangga (Creamer, 1961).

Beberapa metodologi penelitian yang pernah digunakan untuk meneliti peran pendidikan terhadap pendapatan rumah tangga relatif beragam. Misalnya (Xin dan $\mathrm{Wu}, 1998)$ menggunakan data pada perekonomian China dengan model dasar berdasarkan New Growth Theory. Xin dan Wu menggunakan ukuran pendapatan yang dicerminkan berupa jumlah produksi pada suatu rumah tangga. Pendapatan tersebut ditentukan oleh variabel-variabel yang terdiri dari jumlah tahun sekolah dan jumlah tahun pengalaman kerja dari tenaga kerja. Kemudian juga memasukkan variabel input tenaga kerja, stok modal, tanah yang disewa oleh rumah tangga. Pendekatan dalam penelitian ini menggunaan metoda estimasi OLS (Ordinary Least Square).

Penelitian Fafchamps dan Quisumbing (1999) menggunakan data panel negara Pakistan. Model penelitian yang digunakan adalah model maksimasi nilai guna (Utility maximization). Penelitian ini dilakukan untuk melihat pengaruh jumlah tenaga kerja dan vektor karakteristik dari modal manusia terhadap pendapatan rumah tangga. Kemudian juga memasukkan variabel vektor input variabel, peralatan dan input semi tetap (semi-fixed input). Penelitian ini menggunakan metoda IV (Instrumental Variable) untuk melakukan instrumentasi dengan menggunakan ukuran BMI (Body Mass Index) untuk mengukur modal manusia. Hasil penelitian menujukkan bahwa jumlah tenaga kerja dan vektor karakteristik dari modal manusia berpengaruh positif terhadap pendapatan rumah tangganya.

Penelitian Gundersen dan Ziliak (2004), menggunakan data panel tingkat (level) negara bagian pada periode tahun 19812000 di Amerika Serikat. Penelitian dilakukan untuk melihat bagaimana pengaruh struktur keluarga terhadap kemiskinan dan kondisi makroekonomi. Penelitian ini juga memasukkan variabel perbedaan wilayah dan ras. Metoda penelitian yang digunakan oleh Gundersen dan Ziliak adalah estimasi Weighted OLS. Hasil penelitian menunjukkan bahwa struktur keluarga berpengaruh terhadap kemiskinan dan kondisi makroekonomi

Penelitian yang dilakukan oleh Fitzsimons (2007) bertujuan melihat pengaruh resiko perubahan yang terjadi pada pendapatan orang tua, serta bagaimana pengaruhnya terhadap tingkat investasi pada pendidikan anak di Indonesia. Penelitian tersebut menggunakan metoda IV (Instrumental Variable) dengan instrumen yang di pergunakan adalah besarnya curah hujan. Besaran curah hujan digunakan untuk meng-instrumentasi resiko pada pendapatan orang tua tersebut pada tingkat desa. Hasil penelitian menunjukkan bahwa peningkatan risiko pada level desa yang diinstrumentasi dengan curah hujan (atau dihadapkan pada resiko curah hujan) berpengaruh terhadap penurunan tingkat inves tasi pada pendidikan anak.

Penelitian yang dilakukan oleh Purnastuti et al. (2011), melalui penggunaan data IFLS 4 (Indonesian Family Life Survey 4) dengan menggunakan Augmented Mincerian Model perhitungan menggunakan OLS (Ordinary Least Square), ditemukan bukti bahwa tingkat pengembalian pribadi (private return) dari sekolah di Indonesia lebih rendah bila dibandingkan dengan tingkat pengembalian pribadi di negara-negara Asia dan negara berkembang lainnya. Artinya tingkat pengembalian pribadi misalnya besarnya upah yang didapat oleh individu tersebut setelah lulus pendidikan di Indo nesia lebih rendah dibandingkan pengembalian pribadi di negara maju. Ditemukan pula bahwa tingkat pengembalian sekolah dari laki-laki berbeda dengan tingkat pengembalian sekolah perempuan, tingkat pengembalian sekolah anak perempuan lebih tinggi dibandingkan tingkat pengembalian sekolah anak laki-laki. Penelitian yang dilakukan oleh Blau et al. (1988), 
dengan menggunakan model Mincer dengan persamaan model logit untuk aplikasi data negara Nikaragua tahun 1977-1978, untuk melihat pengaruh dari strategi investasi yang berbeda pada pendidikan terhadap pendapatan rumah tangga dan pendapatan (individu). Pengukuran yang dilakukan oleh Blau et al. (1988) adalah dengan memasukan variabel ukuran rumah tangga, status pernikahan dan tingkat partisipasi angkatan kerja. Hasilnya menunjukkan bahwa: (1) Pilihan dalam strategi investasi sekolah memiliki pengaruh yang penting terhadap distribusi pendapatan, (2) Pengaruh tidak langsung dari sekolah (pengaruh imbas, pengaruh bawaan yang tidak langsung) adalah signifikan dan penting terhadap pendapatan rumah tangga, (3) Penurunan pembedaan terhadap pendidikan wanita (peningkatan pemerataan pendidikan terhadap wanita) memiliki efek yang substantif terhadap pemerataan pendapatan.

Penelitian disertasi dari Roope (1999) dengan menggunakan model Mincer yang dimodifikasi, menggunakan data panel negara Finlandia tahun 1970 dan 1982. Metoda pengolahan data menggunakan metoda OLS (Ordinary Least Square) dan IV (Instrumental Variabel). Hasil penelitian menunjukkan bahwa karakteristik rumah tangga sebagai instrumen yaitu pendidikan ibu dan ayah serta pendapatan ibu dan ayah berpengaruh terhadap pilihan pendidikan, termasuk efeknya terhadap biaya dan manfaat (benefit) sekolah. Variasi dari tingkat pengembalian sekolah menunjukkan atau merefleksikan perbedaan dalam modal manusia yang diperolah dari nilai keterampilan yang laku di pasar (marketable) pada lapangan kerja (workplace) yang tersedia.

Penelitian yang dilakukan oleh Chevalier (2004), menggunakan data Inggris 19942002, melalui metoda eksperimen menunjukkan bahwa terdapat pengaruh positif dari pendidikan kedua orang tua (ayah dan ibu) terhadap pencapaian sekolah anak bila diarahkan pada orangtua alamiah/biologis saja (natural parent). Orang tua tiri tidak berpengaruh atau pengaruhnya negatif terhadap pendidikan anak. Penelitian juga menunjukkan estimasi teguh (robust) dengan memasukkan variabel kontrol pendapatan, partisipasi angkatan kerja, kesuburan (fertility) dan kualitas lingkungan tetangga, semuanya menunjukkan bahwa pengaruh dari pendidikan orangtua adalah langsung atau berpengaruh penting terhadap pencapaian sekolah anak.

Penelitian yang dilakukan oleh Jungmin (2004), pada data panel Korea Selatan tahun 1993 dan 1998, menunjukkan bukti kuat bahwa jumlah anak kandung (sibling) memiliki hubungan yang berlawanan (terbalik) terhadap tingkat pendidikan anak, pada kondisi orang tua yang memiliki tingkat kesuburan (fertility) tinggi.

\section{METODE PENELITIAN}

Metode analisis IV pada dasarnya bisa digunakan untuk penelitian dengan menggunakan metode eksperimen maupun non eksperimen. Metoda analisis IV adalah meng-instrumentasi variabel yang kita curigai terpengaruh (endogenous) $(\mathrm{P})$, melalui variabel lain yang mempengaruhi variabel tersebut (Z), tapi tidak berpengaruh langsung pada variabel eksogennya $(\mathrm{Y})$. Metoda IV juga bisa digunakan untuk mengatasi masalah feed back (hubungan timbal balik) antara $(X)$ dengan $(Y)$. Proses pengujian suatu kebijakan dengan menggunakan model IV dilakukan melalui dua tahapan OLS, oleh karena itu model IV pada prakteknya menggunakan model analisis TSLS (Two Stage Least Square)/2SLS. Model dasar dari IV adalah sebagai berikut:

Tahap 1: $Y=\beta_{0}+\beta_{1} X+\beta_{2} P+\varepsilon$

Tahap 2:P $=\delta_{0}+\delta_{1} X+\delta_{2} Z+\tau$

$\operatorname{cov}(\mathrm{Z}, \varepsilon)=0$,

$\operatorname{cov}(Z, \tau) \quad 0$,

$\operatorname{cov}(\mathrm{Z}, \mathrm{P})>0$

Kedua model tersebut menjelaskan bahwa: Tahap 1: variabel $\mathrm{Y}$ dipengaruhi oleh variabel $\mathrm{P}$ (program), dan variabel lainnya $(X)$. Tahap 2: model (1-2) adalah model instrumen untuk variabel $\mathrm{P}$. Pada kedua 
model tersebut fungsi dari IV adalah mengganti variabel $\mathrm{P}$ dengan variabel lain $(\mathrm{Z})$ yang menjelaskan variabel $P$ tersebut tapi tidak berkorelasi dengan errornya $(\varepsilon)$. Variabel $\mathrm{Z}$ disebut sebagai Instrumental Variable. Tiga catatan syarat di bawah model (1-1) dan (1-2) menjelaskan bahwa: syarat pertama adalah variabel instrumen $(Z)$ tidak berkorelasi dengan residu yang diprediksikan (residual predicted; $\varepsilon$ ), kemudian syarat yang kedua adalah bahwa variabel $\mathrm{Z}$ harus berkorelasi dengan $\tau$ (error term) dari model 2 , dan syarat yang ketiga adalah variabel $\mathrm{Z}$ harus berkorelasi dengan variabel program (P). Adapun contoh variabel instrumen yang sering dipergunakan adalah pada pengukuran efek pendidikan anak dengan menggunakan instrumen pendidikan orang tua.

Masalah yang biasanya dihadapi dalam penggunaan metoda IV adalah: (1) Omited variabel, yaitu menghilangkan variabel yang penting, misalnya: disebabkan data tidak ada atau tidak lengkap; atau dihadapkan pada situasi komplikasi (campur-aduk atau situasi saling mempengaruhi), seperti pada contoh kebijakan job training: adanya kemungkinan perbedaan motivasi, perbedaan informasi, dan perbedaan biaya opportunitas (opportunity cost), (2) Partisipan biasanya adalah endogenous (padahal keikutsertaan partisipan secara teori haruslah sukarela), (3) Terjadinya "Endogenous program placement" (tempat pelaksanaan program adalah berpengaruh), misalnya karakteristik desa yaitu potensi dan kondisi desa yang berbeda memungkinkan hasil yang berbeda untuk kebijakan yang sama. Untuk kasus tersebut biasanya dipecahkan dengan melakukan apa yang dikenal dengan istilah "inten-to-treat" (dinaikan ketingkat/level unit analisis yang lebih tinggi; misalnya ke tingkat/level desa).

Model regresi upah dikembangkan oleh Mincer tahun 1958 dan 1974, sedangkan bentuk formalnya dikembangkan oleh Ben-Porath (1967). Model ini diawali dengan pemikiran bahwa akumulasi modal manusia merupakan kaitan (link) antara upah (sebagai variabel observed) dengan kuantitas keterampilan (skill) yang dimiliki oleh individu (sebagai variabel unobserved) dalam pasar tenaga kerja yang berbentuk pasar persaingan sempurna, bila dimodelkan adalah sebagai berikut:

$W_{t}=P_{t} \cdot H_{t}$

Dimana, $W_{t}$ adalah tingkat upah di pasar, $P_{t}$ adalah harga per unit dari keterampilan, dan $H_{t}$ adalah kuantitas dari keterampilan (modal manusia), sehingga:

$\log W_{t}=\log P_{t} .+\log H_{t} \ldots \ldots \ldots \ldots \ldots \ldots(1-4)$

Kontribusi utama dari teori modal manusia ini adalah mengembangkan pendekatan fungsi produksi terhadap spesisifikasi $H_{t}($.$) sehingga memungkinkan diper-$ lakukan sebagai variabel yang terobservasi (observable variable) melalui perhitungan alokasi waktu (time allocation).

Model regresi Mincer pada prinsipnya menjelaskan mengenai terdapatnya hubungan yang kuat dan jelas antara upah pasar, pendidikan dan pengalaman. Pada tahap tersebut persamaan upah Mincer masih bersifat deskriptif dan belum bersifat informatif mengenai jumlah optimal dari sekolah (hal tersebut adalah tipikal pemikiran yang dikembangkan di bawah asumsi exogenous dari akumulasi modal manusia). Model ini mendefinikan (menterjemahkan) sebagai berikut: Variabel $E_{t}$ adalah penerimaan potensial (potential earning) pada waktu $t$ (bila bekerja penuh; full time). Dalam hal ini $E_{t}$ adalah sebagai modal manusia. Kemudian $c_{t}=k_{t} \cdot E_{t}$ sebagai investasi dalam modal manusia (misalnya pelatihan). Sedangkan $k_{t}$ adalah jumlah dari waktu (exogenous) terhadap pelatihan $\left(k_{t}=1\right.$ pada sekolah). Kemudian $\rho_{t}$ adalah pengembalian dari pelatihan (atau sekolah), maka: $E_{t+1}=E_{t}+$ $c_{t} \cdot \rho_{t}=E_{t}\left(1+k_{t} \cdot \rho_{t}\right)$, Secara umum, dimulai dari periode 0 (pengembalian potensial pada 0 adalah $\left.E_{0}\right), E_{t}=\left[\prod_{j=0}^{t-1}\left(1+k_{j} . \rho_{j}\right)\right] E_{0}$

Selanjutnya dibagi horizon kedalam 2 periode (periode sekolah dan pasca sekolah; pelatihan). Dimana $\rho_{t}=\rho_{s}$ (di sekolah), $\rho_{t}=\rho_{0}$ (pada aktivitas pelatihan), (s=school, $o=$ training), 
$E_{s}=\left[\left(1+\rho_{s}\right)^{s} \cdot E_{0}\right.$, sehingga:

$E_{t}=\left[\prod_{j=s}^{t-1}\left(1+k_{j} \cdot \rho_{0}\right)\right]\left(1+\rho_{s}\right)^{s} \cdot E_{0}$,

Selanjutnya persamaan pengembalian potensial (potential earning) tersebut di logkan, dengan catatan bahwa $\rho_{0}$ maupun $\rho_{S}$ keduanya nilainya kecil, maka:

$\ln E_{t}=\ln E_{0}+s . \rho_{s}+\rho_{0} . \sum_{j=s}^{t-1} k_{j}$

Tahap berikutnya adalah memperkenalkan elemen pengalaman $(X)$ dalam persamaan tersebut. Caranya adalah dengan membuat variabel $k_{j}(X)$ sebagai tingkat eksogen dari akumulasi modal sepanjang menyelesaikan sekolah. Catatannya adalah: $\mathrm{t}=\mathrm{T}-\mathrm{s}=\mathrm{X} ;(\mathrm{t}=\mathrm{be}-$ kerja penuh, $\mathrm{T}=$ total waktu, $\mathrm{s}=$ sekolah), sehingga akhirnya menjadi Mincer Wage regression:

$\ln (w(s, x))=\alpha_{0}+\rho_{s} \cdot S+\beta_{0} \cdot X+\beta_{1} \cdot X^{2} . .(1-5)$

Bahwa ketika di turunkan terhadap (.), nilai dari intersep adalah harga sekarang dari log produk keterampilan dan kemampuan awal, $\rho_{s}$ adalah pengembalian dari sekolah, $\beta_{0} / \beta_{1}$ adalah pengembalian dari pengalaman (hal ini merefleksikan kecembungan kurva pengembalian terhadap usia ketika $\beta_{1}$ negatif). Ketikan (.) bertambah (augmented) pada kasus ras/jenis kelamin, maka hal tersebut akan berguna untuk digunakan dalam studi tentang diskriminasi.

Adapun bentuk ekonometrika standar dari Mincer Wage Regression adalah sebagai berikut:

$\log W_{t}=w_{t}=\beta_{0}+\beta_{1}$. Schooling $t+$ $\beta_{2} \cdot \exp _{t}+\beta_{3} \cdot \exp _{t}^{2}+\varepsilon_{t}$

$W$ adalah upah, Schooling adalah waktu sekolah dan exp adalah jumlah waktu dari pengalaman kerja.

Sebagaimana perkembangan teori pada umumnya, maka terdapat kelebihan dan kekurangan dari model Mincer. Beberapa kelebihan dan kelemahan model Mincer adalah: a) Tingkat pengembalian (earning) dari kelompok pendidikan yang berbeda dianggap pengembaliannya sama (paralel), b) Tingkat pengembalian dari pengalaman dianggap sebagai pengembalian modal manusia secara umum (general), c) Mincer menganggap bahwa tingkat produktifitas meningkat sejalan dengan pengalaman melaui: proses belajar sambil bekerja (learningby-doing), terdapat investasi secara ekplisit pada pelatihan (training), d) Model Mincer menjelaskan sebab tingkat pengembalian pekerja yang lebih tua (older workers) menurun adalah: terjadinya penyusutan (depresiasi) pada modal manusia, tidak terjadinya penggantian yang cukup terhadap penyusutan tersebut, e) Meskipun penjelasan model Mincer banyak membuktikan kebenarannya, tapi apakah benar untuk seluruh kondisi?, f) Pada kenyataannya terdapatnya pekerja yang bekerja tidak sesuai dengan keahliannya (displace workers), pekerja yang lebih tua (berpengalaman) kehilangan pekerjaanya pada saat perusahaan mengalami kerugian besar, g) Pada banyak kasus menunjukkan bahwa pekerja yang lebih tua akan lebih produktif menunjukkan bukti yang tidak terlalu kuat (lemah).

Model yang akan dipergunakan dalam penelitian ini adalah model yang dikembangkan oleh Mincer $(1958,1974)$ yang dimodifikasi oleh penulis. Proses modifikasi dilakukan melalui tahapan sebagai berikut: 1) Model Mincer dijadikan kerangka dasar dalam keberhasilannya menjelaskan hubungan antara pendidikan dan pengalaman terhadap pendapatan upah rumah tangga. 2) Selanjutnya dilakukan instrumentasi terhadap variabel pendidikan dengan menggunakan metoda IV (Instrumental Variabel) instrumennya adalah jumlah anak kandung (Sibling) dan tingkat pendidikan orang tua (EducHead). 3) Selanjutnya terhadap model tersebut dilakukan proses perbandingan dengan menggunakan ukuran variabel upah dan juga variabel pendapatan total dari rumah tangga.

Untuk mengukur pengaruh sumber daya manusia terhadap pendapatan rumah tangga, maka sesuai dengan teori yang melatarbelakangi model Mincer bahwa penelitian ini akan memusatkan perhatian pada aspek pendidikan dan pengalaman. Kedua aspek tersebut diyakini merupakan 
komponen utama sebagai penentu kualitas sumber daya manusia. Walaupun harus diakui ada beberapa faktor lain yang juga ikut menentukan kualitas sumber daya manusia seperti kualitas makanan, kualitas sanitasi, faktor keturunan dan lain sebagainya.

Model regresi upah dari Mincer adalah model yang secara spesifik mencoba menjelaskan mengenai pengaruh pendidikan (dan pengalaman) terhadap upah (wage). Komponen utama yang diukur dari model tersebut adalah sekolah (schooling) dan pengalaman (experience). Pemilihan model Mincer dalam penelitian yang akan dilakukan dengan ukuran utama upah didasari pemikiran bahwa upah merupakan konponen utama dari kebanyakan rumah tangga dimanapun. Perbedaan penelitian yang akan dilakukan dibandingkan dengan model standarnya adalah bahwa unit analisis yang digunakan adalah unit rumah tangga, sehingga ukuran dari variabel upah yang akan dipakai adalah rata-rata upah di keluarga dan rata-rata pendapatan tersebut (sebagai perbandingan juga akan dicobakan ukuran total upah dan total pendapatan), ukuran sekolah adalah rata-rata lama pendidikan, dan ukuran pengalaman adalah rata-rata pengalaman.

Terhadap model Mincer tersebut selanjutnya akan dilakukan proses instrumentasi dengan menggunakan metoda IV. Variabel yang akan dilakukan instrumentasi adalah variabel pendidikan. Penggunaan metoda IV adalah salah satu cara untuk menghilang endogeneity. Instrument yang umumnya digunakan adalah pendidikan orang tua (pendidikan ibu, pendidikan ayah, atau pendidikan keduanya). Pada penelitian ini akan digunakan instrumen jumlah anak kandung sekaligus juga tingkat pendidikan orangtua, dengan alasan sebagai berikut: (1) Komponen anak kandung adalah bagian utama dari keluarga inti, (2) Jumlah anak kandung akan mempangaruhi terhadap pendidikan anggota keluarga, dengan asumsi semakin banyak anak kandung akan semakin rendahnya rata-rata pendidikan anggota keluarga, (3) Penggunaan instrumen tingkat pendidikan orang tua dilakukan sebagai pembanding dari instrumen anak kandung.

Bentuk ekonometrika standar dari Mincer Wage Regression adalah sebagaimana yang sudah dijelaskan dibagian depan adalah sebagai berikut:

$\log$ Wage $_{t}=\beta_{0}+\beta_{1}$. Schooling $t+\beta_{2} \cdot \exp _{t}+$ $\beta_{3} \cdot \exp _{t}^{2}+\varepsilon_{t} \ldots \ldots \ldots \ldots \ldots \ldots \ldots \ldots \ldots \ldots \ldots \ldots \ldots \ldots \ldots . .(1-7)$

Selanjutnya model tersebut diubah disesesuaikan dengan tujuan penelitian ini, yaitu:

$\ln H I_{t}=\ln$ Wage $_{t}=\beta_{0}+\beta_{1}$.Educ_mean $t+$ $\beta_{2} \cdot \exp _{t}+\beta_{3} \cdot \exp _{t}^{2}+\varepsilon_{t} \ldots \ldots \ldots \ldots \ldots \ldots \ldots . .(1-8)$

Selanjutnya model instrumen yang akan digunakan adalah:

Educ_mean $_{t}=\delta_{0}+\delta_{1}$. Sibling $_{t}+\tau_{t} \ldots \ldots .(1-9)$

Educ_mean $_{t}=\delta_{0}+\delta_{1}$. EducHead $t+\tau_{t}$

Keterangan:

$H I=$ Wage $=$ Total pendapatan rumah tangga dan upah (Rupiah)

Educ_mean=Pendidikan (rata-rata tahun pendidikan) dari anggota rumah tangga

Exp=Pengalaman (rata-rata tahun pengalaman kerja) dari anggota rumah tangga

Sibling=Jumlah anak kandung dalam rumah tangga tersebut (orang)

EducHead=Tingkat pendidikan kepala rumah tangga

$\beta=$ Koefisien pada persamaan upah

$\delta=$ Koefisien pada persamaan pendidikan

$\varepsilon=$ Error term pada persamaan upah

$\tau=$ Error term pada persamaan pendidikan $\mathrm{t}=$ Waktu

Terdapat beberapa kemungkinan kontribusi dari penelitan ini. Keyakinan terhadap kontribusi penelitian ini didukung oleh adanya beberapa perbedaan dibandingkan penelitian-penelitian sebelumnya, yaitu: (a) Pada berbagai penelitian yang terdahulu umumnya menggunakan unit analisis individu. Pada penelitian ini menggunakan unit analisis rumah tangga. Artinya penelitian ini akan menguji pengaruh pendidikan dan pengalaman terhadap pendapatan dalam lingkup rumah 
tangga di Indonesia. (b) Pada penelitian sebelumnya ukuran yang digunakan untuk pendapatan adalah upah, dalam penelitian ini juga akan digunakan total pendapatan rumah tangga, karena komponen upah dalam masyarakat pedesaan tidak menggambarkan pendapatan yang sesungguhnya karena komponen upah relatf kecil. (c) Instrumen yang digunakan terhadap model Mincer Wage Regression dalam model IV (Instrumental Variabel) umumnya adalah pendidikan orang tua (EducHead= ayah, ibu, atau keduanya), pada penelitian ini juga akan juga dipergunakan instrumen jumlah anak kan- dung (sibling).

Data yang dipergunakan adalah data panel yang bersumber dari IFLS (Indonesian Family Life Survey). Alasan penggunaan IFLS adalah sebagai berikut: (a) Data yang dikumpulkan dalam publikasi IFLS adalah data panel (panel data), yaitu kelompok data yang sering disebut juga data longitudinal (longitudinal data). Berbeda dengan data antar waktu (cross section) maupun data deret waktu (time series), data panel dikumpulkan berdasarkan unit yang sama (individu, keluarga, perusahaan, kota, negara, dan lainnya) antar waktu (Woolridge, 2009). (b) Seluruh komponen data yang diperlukan dalam penelitian ini semuanya tersedia dalam cakupan data IFLS. Keseluruhan data tersebut mencakup datadata indikator dari seluruh variabel dalam model yang digunakan dalam penelitian ini. Berdasarkan kedua alasan tersebut di atas, maka diharapkan penggunaan data IFLS pada penelitian ini mampu memberikan informasi yang utuh dan kuat (signifikan). Artinya mampu melakukan penelusuran mengenai perubahan pada unit rumah tangga yang sama antar waktu secara tajam. Selain alasan tersebut di atas, data IFLS sudah diakui secara internasional memiliki kualitas data yang baik, terutama karena memiliki tingkat ketidaksinambungan (attrition) data yang rendah, atau rendahnya tingkat kehilangan data pada individu yang sama antar waktu. Cakupan data IFLS meliputi data dari 13 propinsi, 321 data komunitas (kelurahan/desa) dan sekitar 22.000 data individual.

Adapun data IFLS yang akan digunakan dalam penelitian ini adalah IFLS-3 tahun 2000 dan IFLS-4 tahun 2007. Alasan penggunaan dua survey tersebut karena: (a) Penggunaan dua titik waktu yaitu tahun 2000 dan tahun 2007 mencukupi kebutuhan data untuk analisis pengujian perubahan pada variabel yang diteliti pada sebuah rentang antar waktu. (b) Kedua kelompok data tersebut adalah dua gelombang survey (wave) yang terakhir dilakukan, sehingga informasi yang diharapkan terkini pada variabel-variabel yang akan diuji dalam penelitian tersebut. Pengolahan data akan menggunakan perangkat lunak (software) STATA.

Data IFLS merangkum 13 data panel propinsi yang mewakili Indonesia secara keseluruhan. Data tersebut meliputi empat pulau besar selain pulau papua, yaitu: Pulau Sumatra meliputi Sumatra Selatan, Sumatra Barat, Lampung dan Sumatra Utara, Pulau Jawa meliputi DKI Jakarta, Jawa Barat, Jawa Tengah, Jawa Timur dan DI Yogyakarta, Pulau Kalimantan meliputi Kalimantan Selatan, Pulau Bali dan Nusa Tenggara meliputi Bali dan Nusa Tenggara Barat, Kepulauan sulawesi diwakili oleh Sulawesi Selatan.

Proses pengolahan data dan sistematika pembahasan akan dilakukan secara bertahap. Tahap 1 adalah pengujian validitas terhadap variabel instrumen yang akan digunakan. Pada tahap ini akan dilakukan regresi variabel Sibling, SiblStay, EducHead, EdParent masing-masing terhadap educ_ mean. Hasil dari tahap ini akan menentukan variabel mana yang layak digunakan sebagai variabel instrumen. Variabel yang akan digunakan adalah variabel yang menunjukkan pengaruh yang signifikan terhadap Educ_mean.

Tahap ke-2 adalah menguji pengaruh dari variabel Educ_mean, Exp_mean, dan Exp_mean2 terhadap In_HI, In_HI_mean, ln_Wage, In_Wage_mean. Pada tahapan ini akan diketahui variabel-variabel mana yang 
berpengaruh paling kuat dan signifikan terhadap variabel-variabel dependennya (ln_HI, ln_HI_mean, In_Wage, In_Wage_ mean). Hasil tahapan ini akan dipergunakan untuk memasukkan variabel instrumen yang sudah terpilih pada tahapan 1.

Tahap ke-3 adalah melakukan proses instrumentasi menggunakan metoda IV melalui dua tahapan OLS atau 2SLS (atau TSLS). Pada tahapan ini akan diketahui instrumen mana (hasil tahap 1) yang paling kuat mempengaruhi secara langsung terhadap pendidikan (hasil tahap 2), dan berpengaruh kuat dan tidak langsung terhadap pendapatan rumah tangga (hasil tahap-3). Selanjutnya Tahap ke-4 adalah dilakukan pengujian melalui test-F dari $\mathrm{Wu}$ Housman test untuk menguji bahwa model tersebut terbebas dari pengaruh endogeneity (Catatan: Masalah endogeneity terjadi ketika terdapat variabel yang mempengaruhi variabel dependen $(\mathrm{Y})$, ternyata tidak bisa ditangkap pada variabel independennya (X), akhirnya akan ditangkap pada variabel error-nya ( ), sehingga model yang dibuat tersebut tidak bisa menjelaskan dengan lengkap dan kuat terhadap kondisi yang sesungguhnya).

\section{ANALISIS DAN PEMBAHASAN}

Berdasarkan perhitungan tentang pengaruh jumlah anak kandung (Sibling) terhadap rata-rata pendidikan pekerja di rumah tangga (Educ_mean) menunjukkan tidak terdapat pengaruh yang signifikan (Tabel 2).

Tabel 2

Pengaruh Jumlah Anak Kandung dan Pendidikan Orang Tua Terhadap Rata-Rata Pendidikan Pekerja di Rumah Tangga

\begin{tabular}{lcccc}
\hline \hline & $\begin{array}{c}(\mathbf{1}) \\
\text { Educ_mean }\end{array}$ & $\begin{array}{c}(\mathbf{2}) \\
\text { Educ_mean }\end{array}$ & $\begin{array}{c}(\mathbf{3}) \\
\text { Educ_mean }\end{array}$ & $\begin{array}{c}(\mathbf{4}) \\
\text { Educ_mean }\end{array}$ \\
\hline Sibling & 0.0399 & & & \\
SiblStay & $(0.0265)$ & & & \\
& & -0.00193 & & \\
EducHead & & $(0.0376)$ & & \\
& & & $0.540^{* * *}$ & \\
EdParent & & $(0.00544)$ & \\
& & & & $0.312^{* * *}$ \\
_cons & & & & $(0.00291)$ \\
& & & & \\
N & $(0.0305)$ & $(0.0290)$ & $\left(0.0542^{* * *}\right.$ & $5.490^{* * *}$ \\
R-sq & 21710 & 21710 & 21710 & $(0.0423)$ \\
adj. R-sq & 0.000 & 0.000 & 0.458 & 21710 \\
rmse & 0.000 & -0.000 & 0.458 & 0.368 \\
S & 3.858 & 3.858 & 2.840 & 0.368 \\
\hline
\end{tabular}

Standard errors in parentheses

${ }^{*} \mathrm{p}<0.05,{ }^{* *} \mathrm{p}<0.01,{ }^{* * *} \mathrm{p}<0.001$

Sumber : keluaran (output) hasil pengolahan data

Pengaruh yang tidak signifikan tersebut ditunjukkan oleh pengaruh jumlah anak kandung yang tinggal di rumah tangga tersebut (SiblStay) terhadap rata-rata pendidikan pekerja di rumah tangga, sedangkan tingkat pendidikan orang tua (EducHead) menunjukkan pengaruh yang signifikan terhadap rata-rata pendidikan pekerja (Educ_mean) di rumah tangga. Hal tersebut ditunjukkan tidak hanya dengan menggunakan ukuran pendidikan kepala rumah tangga tapi dengan menggunakan ukuran pendidikan kedua orang tua (EdParent). Penjelasan mengenai tidak 
signifikannya jumlah anak terhadap ratarata pendidikan pekerja di rumah tangga tersebut adalah karena rata-rata pendidikan di Indonesia masih sekitar lulus SD (Sekolah Dasar) yaitu pada angka rata-rata 8,7 tahun (Tabel 3), komponen biaya tingkat pendidikan SD lebih banyak ditanggung oleh pemerintah, sehingga tidak signifikan (tidak memiliki hubungan yang kuat) secara langsung dengan tingkat pendidikan pekerja di rumah tangga, maupun hubungan tidak langsung terhadap pendapatan dan upah rumah tangga. Hal tersebut juga didukung oleh data yang diterbitkan oleh Bank Dunia bahwa rata-rata tahun sekolah seluruh penduduk Indonesia adalah 5,8 tahun, atau rata-rata pendidikan Sekolah Dasar (Tabel 1). Hasil penelitian bertolak belakang dengan hasil penelitian yang dilakukan oleh Junming (2004) yang menunjukkan bahwa terdapat bukti kuat bahwa jumlah anak kandung (sibling) memiliki hubungan yang berlawanan (terbalik) terhadap tingkat pendidikan anak, pada kondi si orang tua kesuburannya (fertility) tinggi.

Tabel 3

Ringkasan Statistik

\begin{tabular}{lrrrrr}
\hline \hline \multicolumn{1}{c}{ Variable } & Obs & Mean & Std. Dev. & Min & Max \\
\hline HI & 21710 & $1.56 \mathrm{e}+07$ & $3.74 \mathrm{e}+07$ & 1400 & $2.01 \mathrm{e}+09$ \\
HI_mean & 21710 & 8175835 & $1.78 \mathrm{e}+07$ & 1400 & $1.00 \mathrm{e}+09$ \\
ln_HI & 21710 & 15.80163 & 1.277468 & 7.244227 & 21.41891 \\
ln_HI_mean & 21710 & 15.24773 & 1.199073 & 7.244227 & 20.72327 \\
Wage & 21710 & $1.47 \mathrm{e}+07$ & $3.54 \mathrm{e}+07$ & 1400 & $2.01 \mathrm{e}+09$ \\
Wage_mean & 21710 & 7816499 & $1.73 \mathrm{e}+07$ & 1400 & $1.00 \mathrm{e}+09$ \\
ln_Wage & 21710 & 15.74757 & 1.27809 & 7.244227 & 21.41891 \\
ln_Wage_mn & 21710 & 15.19367 & 1.209104 & 7.244227 & 20.72327 \\
Educ_mean & 21710 & 8.717777 & 3.858128 & 0 & 24 \\
Exp_mean & 21710 & 21.70716 & 12.13016 & -5 & 68 \\
Exp_mean2 & 21710 & 618.3349 & 698.2286 & 0 & 4624 \\
AgeL_mean & 21710 & 37.42494 & 10.43596 & 10 & 75 \\
EdParent & 21710 & 10.33842 & 7.49783 & 0 & 41 \\
EducHead & 21710 & 7.417642 & 4.835905 & 0 & 29 \\
Sibling & 21710 & 0.4452326 & 0.8690157 & 0 & 8 \\
SiblStay & 21710 & 0.2542607 & 0.6015044 & 0 & 5 \\
\hline
\end{tabular}

Sumber : keluaran (output) hasil pengolahan data

Adapun pengaruh rata-rata pendidikan pekerja di rumah tangga dan pengalaman kerja terhadap pendapatan rumah tangga adalah signifikan terhadap pendapatan maupun terhadap upah rumah tangga (Tabel 4). Kedua variabel tersebut signifikan tidak hanya terhadap total tapi juga terhadap rata-rata upah rumah tangga maupun pendapatan rumah tangga (upah ditambah pendapatan bersih dari usaha pertanian dan Non-pertanian). Berdasarkan tabel 4 tersebut, ternyata model yang menjelaskan kaitan paling kuat di antara variabel tersebut adalah model 4, yaitu kaitan antara pendidikan rata-rata pekerja dan pengalaman kerja terhadap rata-rata upah di rumah tangga. Penjelasan dari hal tersebut adalah karena variabel pendidikan dan pengalaman menggunakan ukuran anggota rumah tangga yang bekerja sehingga berkaitan langsung dengan upah. Hasil penelitian ini sejalan dengan hasil 
penelitian yang dilakukan oleh Blau et al. (1988), yang menunjukkan bahwa: (a) Pilihan dalam strategi investasi sekolah memiliki pengaruh yang penting terhadap distribusi pendapatan, (b) pengaruh tidak langsung dari sekolah adalah signifikan dan penting.

Tabel 4

Pengaruh Pendidikan dan Pengalaman Terhadap Pendapatan Rumah Tangga

\begin{tabular}{lcccc}
\hline \hline & $\mathbf{( 1 )}$ & $\mathbf{( 2 )}$ & $\mathbf{( 3 )}$ & $\mathbf{( 4 )}$ \\
& $\mathbf{l n \_ H I}$ & $\mathbf{l n} \_$Wage & ln_HI_mean & ln_Wage_mn \\
\hline Educ_mean & $0.164^{* * *}$ & $0.167^{* * *}$ & $0.174^{* * *}$ & $0.178^{* * *}$ \\
Exp_mean & $(0.00240)$ & $(0.00240)$ & $(0.00227)$ & $(0.00228)$ \\
& $0.0678^{* * *}$ & $0.0665^{* * *}$ & $0.0406^{* * *}$ & $0.0392^{* * *}$ \\
Exp_mean2 & $(0.00231)$ & $(0.00231)$ & $(0.00216)$ & $(0.00217)$ \\
& $-0.00119^{* * *}$ & $-0.00116^{* * *}$ & $-0.000601^{* * *}$ & $-0.000577^{* * *}$ \\
_cons & $(0.0000402)$ & $(0.0000405)$ & $(0.0000379)$ & $(0.0000382)$ \\
& $13.63^{* * *}$ & $13.56^{* * *}$ & $13.22^{* * *}$ & $13.15^{* * *}$ \\
N & $(0.0427)$ & $(0.0426)$ & $(0.0402)$ & $(0.0403)$ \\
R-sq & 21710 & 21710 & 21710 & 21710 \\
adj. R-sq & 0.263 & 0.271 & 0.278 & 0.283 \\
rmse & 0.263 & 0.271 & 0.277 & 0.283 \\
\hline
\end{tabular}

Standard errors in parentheses

${ }^{*} \mathrm{p}<0.05,{ }^{* *} \mathrm{p}<0.01,{ }^{* * *} \mathrm{p}<0.001$

Sumber : keluaran (output) hasil pengolahan data

Berdasarkan hasil perhitungan menunjukkan bahwa yang bisa digunakan sebagai variabel instrumen dalam metoda Instrumental Variable (IV) adalah variabel pendidikan kepala rumah tangga (Educ Head) dan pendidikan kedua orang tua (EdParent). Kepala rumah tangga adalah pimpinan rumah tangga bisa ayah atau ibu (apabila ayah tidak ada), sedangkan kedua orang tua adalah ayah dan ibu. Selanjutnya setelah dilakukan perhitungan dengan menggunakan kedua instrumen tersebut ternyata kedua ukuran tersebut menunjukkan hasil yang sama baiknya (Tabel 5 dan Tabel 6). Artinya bahwa secara statistik terbukti ke 8 model tersebut (4 model dengan instrumen EducHead dan 4 model dengan instrumen EdParent) menunjukkan hubungan yang signifikan. Berdasarkan data statistik deskriptif (Tabel 3) rata-rata pendidikan orang tua adalah 7,4 tahun atau rata-rata tamat Sekolah Dasar. Sedangkan rata-rata pendidikan gabungan dari ayah dan/atau ibu adalah 10,3 tahun.

Hasil penelitian sejalan dengan hasil penelitian yang dilakukan oleh Rope (1999) dalam disertasinya menunjukkan bahwa karakteristik rumah tangga sebagai instrumen yaitu pendidikan ibu dan ayah serta pendapatan ibu dan ayah berpengaruh terhadap pilihan pendidikan, termasuk efeknya terhadap biaya dan keuntungan (benefit) sekolah.

Hasil penelitian tersebut juga sejalan dengan hasil penelitian yang dilakukan oleh Chevalier (2004), yang menunjukkan bahwa terdapat pengaruh positif dari pendidikan kedua orang tua (ayah dan ibu) terhadap pencapaian sekolah anak bila diarahkan pada orangtua alamiah/biologis saja (natural parent).

Penelitian juga menunjukkan estimasi adalah teguh (robust) dengan memasukkan variabel control pendapatan, partisipasi 
Tabel 5

Pengaruh Pendidikan dan Pengalaman terhadap Pendapatan Rumah Tangga dengan Instrumen EducHead

\begin{tabular}{lcccc}
\hline \hline & $\mathbf{( 1 )}$ & $\mathbf{( 2 )}$ & $\mathbf{( 3 )}$ & $\mathbf{( 4 )}$ \\
& $\mathbf{l n}$ _HI & $\mathbf{l n}$ _Wage & ln_HI_mean & ln_Wage_mn \\
\hline Educ_mean & $0.172^{* * *}$ & $0.175^{* * *}$ & $0.200^{* * *}$ & $0.203^{* * *}$ \\
& $(0.00371)$ & $(0.00369)$ & $(0.00346)$ & $(0.00347)$ \\
Exp_mean & $0.0696^{* * *}$ & $0.0682^{* * *}$ & $0.0462^{* * *}$ & $0.0448^{* * *}$ \\
& $(0.00212)$ & $(0.00211)$ & $(0.00198)$ & $(0.00199)$ \\
Exp_mean2 & $-0.00119^{* * *}$ & $-0.00117^{* * *}$ & $-0.000620^{* * *}$ & $-0.000596^{* * *}$ \\
& $(0.0000341)$ & $(0.0000339)$ & $(0.0000318)$ & $(0.0000319)$ \\
_cons & $13.53^{* * *}$ & $13.46^{* * *}$ & $12.89^{* * *}$ & $12.82^{* * *}$ \\
& $(0.0543)$ & $(0.0541)$ & $(0.0506)$ & $(0.0509)$ \\
N & 21710 & 21710 & 21710 & 21710 \\
R-sq & 0.263 & 0.271 & 0.273 & 0.279 \\
adj. R-sq & 0.263 & 0.271 & 0.273 & 0.279 \\
rmse & 1.097 & 1.091 & 1.022 & 1.027 \\
\hline
\end{tabular}

Standard errors in parentheses

${ }^{*} \mathrm{p}<0.05,{ }^{* *} \mathrm{p}<0.01,{ }^{* * *} \mathrm{p}<0.001$

Sumber : keluaran (output) hasil pengolahan data

Tabel 6

Pengaruh Pendidikan dan Pengalaman terhadap Pendapatan Rumah Tangga dengan Instrumen EdParent

\begin{tabular}{|c|c|c|c|c|}
\hline & $\begin{array}{c}(1) \\
\ln \_ \text {HI }\end{array}$ & $\begin{array}{c}(2) \\
\ln \_ \text {Wage }\end{array}$ & $\begin{array}{c}(3) \\
\text { ln_HI_mean }\end{array}$ & $\begin{array}{c}(4) \\
\text { ln_Wage_mn }\end{array}$ \\
\hline Educ_mean & $\begin{array}{c}0.217^{* * *} \\
(0.00416)\end{array}$ & $\begin{array}{c}0.215^{* * *} \\
(0.00413)\end{array}$ & $\begin{array}{l}0.175^{* * *} \\
(0.00382)\end{array}$ & $\begin{array}{l}0.173^{* * *} \\
(0.00383)\end{array}$ \\
\hline Exp_mean & $\begin{array}{l}0.0796^{* * *} \\
(0.00218)\end{array}$ & $\begin{array}{l}0.0770 * * * \\
(0.00217)\end{array}$ & $\begin{array}{l}0.0408^{\star * *} \\
(0.00201)\end{array}$ & $\begin{array}{l}0.0382^{* * *} \\
(0.00201)\end{array}$ \\
\hline Exp_mean2 & $\begin{array}{l}-0.00123^{* * *} \\
(0.0000345)\end{array}$ & $\begin{array}{l}-0.00120^{* * *} \\
(0.0000343)\end{array}$ & $\begin{array}{c}-0.000602^{* * *} \\
(0.0000317)\end{array}$ & $\begin{array}{c}-0.000573^{* * *} \\
(0.0000319)\end{array}$ \\
\hline _cons & $\begin{array}{l}12.94^{* * *} \\
(0.0597)\end{array}$ & $\begin{array}{l}12.94^{* * *} \\
(0.0593)\end{array}$ & $\begin{array}{l}13.20 * * * \\
(0.0549)\end{array}$ & $\begin{array}{l}13.21^{* * *} \\
(0.0551)\end{array}$ \\
\hline $\mathrm{N}$ & 21710 & 21710 & 21710 & 21710 \\
\hline R-sq & 0.246 & 0.257 & 0.278 & 0.283 \\
\hline adj. R-sq & 0.246 & 0.257 & 0.277 & 0.283 \\
\hline rmse & 1.109 & 1.102 & 1.019 & 1.024 \\
\hline
\end{tabular}

Standard errors in parentheses

${ }^{*} \mathrm{p}<0.05,{ }^{* *} \mathrm{p}<0.01,{ }^{* * *} \mathrm{p}<0.001$

Sumber: keluaran (output) hasil pengolahan data

angkatan kerja, kesuburan (fertility) dan kualitas lingkungan tetangga, semuanya menunjukkan bahwa pengaruh pendidikan orangtua adalah langsung. Selanjutnya setelah dilakukan uji endogeneity melalui
Wu-Hausman F-test terbukti ke 8 model tersebut bebas dari endogeneity (Catatan: Masalah endogeneity terjadi ketika terdapat variabel yang mempengaruhi variabel dependen $(\mathrm{Y})$, ternyata tidak bisa ditangkap 
pada variabel independennya $(X)$, akhirnya akan ditangkap pada variabel error-nya ( ), sehingga model yang dibuat tersebut tidak bisa menjelaskan dengan lengkap dan kuat terhadap kondisi yang sesungguhnya), akan tetapi untuk memenuhi syarat keteguhan model tersebut mengharuskan F-test $>10$, sehingga yang benar-benar teguh adalah model pengaruh EducHead terhadap ratarata upah rumah tangga (HI_mean) dan terhadap rata-rata pendapatan rumah tangga (Wage_mean), serta pengaruh EdParent terhadap total pendapatan rumah tangga (HI) dan terhadap total upah rumah tangga (Wage). Artinya baik EducHead maupun EdParent mempengaruhi secara langsung terhadap rata-rata pendidikan pekerja di rumah tanggga (variabel $\mathrm{X}$ ), tapi tidak berpengaruh langsung terhadap pendapatan atau upah rumah tangga (variabel $Y$ ), sehingga bisa disimpulkan bahwa tingkat pendidikan orangtua (kepala rumah tangga maupun gabungan ayah dan ibu) mempengaruhi secara langsung dan signifikan terhadap rata-rata pendidikan pekerja di rumah tangga dan mempengaruhi secara tidak langsung dan signifikan terhadap pendapatan atau upah rumah tangga di Indonesia.

Dapat disimpulkan bahwa pengaruh pendidikan terhadap pendapatan atau upah, pengaruh pengalaman terhadap pendapatan atau upah, dan pengaruh pendidikan orang tua dan kepala rumah tangga terhadap pendidikan pekerja di rumah tangga adalah berpengaruh kuat dan signifikan. Adapun pengaruh jumlah anak kandung terhadap pendidikan pekerja di rumah tangga tidak berpengaruh signifikan karena tidak terbukti bahwa jumlah anak kandung mempengaruhi secara langsung terhadap rata-rata pendidikan pekerja di rumah tangga maupun mempengaruhi secara tidak langsung terhadap pendapatan atau upah dari rumah tangga tersebut.

Hasil penelitian ini sesuai dengan hasil penelitian yang sudah dilakukan oleh Ravallion dan Wodon (2000); Fafchamps dan Quisumbing (1999); Creamer (1961);
Xin dan Wu (1998) bahwa peningkatan tingkat pendidikan berpengaruh positif dan signifikan terhadap peningkatan pendapatan (individu/rumah tangga). Kemudian hasil penelitian ini sesuai dengan hasil penelitian yang sudah dilakukan oleh Xin dan $\mathrm{Wu}$ (1998) bahwa peningkatan tingkat pengalaman berpengaruh positif dan signifikan terhadap peningkatan pendapatan (individu/rumah tangga).

\section{SIMPULAN DAN SARAN Simpulan}

Berdasarkan hasil penelitian, maka dapat disimpulkan bahwa pengaruh jumlah anak kandung terhadap rata-rata pendidikan pekerja di rumah tangga menunjukkan tidak terdapat pengaruh yang signifikan. Artinya banyaknya jumlah anak kandung tidak berpengaruh terhadap tingkat pendidikan pekerja di rumah tangga, sedangkan tingkat pendidikan orang tua menunjukkan pengaruh yang signifikan terhadap rata-rata pendidikan pekerja di rumah tangga. Hal tersebut ditunjukkan tidak hanya dengan menggunakan ukuran pendidikan kepala rumah tanggga tapi juga dengan menggunakan ukuran pendidikan kedua orang tua.

Pengaruh rata-rata pendidikan pekerja di rumah tangga dan pengalaman kerja terhadap pendapatan rumah tangga adalah signifikan terhadap pendapatan maupun upah rumah tangga. Artinya tingat pendidikan dan pengalaman pekerja berpengaruh terhadap pendapatan rumah tangga. Kedua variabel tersebut signifikan tidak hanya terhadap total tapi juga terhadap rata-rata upah rumah tangga maupun pendapatan rumah tangga.

Variabel yang bisa dipergunakan sebagai variabel instrumen dalam metoda Instrumental Variable (IV) adalah variabel pendidikan kepala rumah tangga dan pendidikan kedua orang tua. Selanjutnya setelah dilakukan perhitungan dengan menggunakan kedua instrumen tersebut ternyata yang benar-benar teguh adalah model pengaruh pendidikan kepala rumah tangga 
terhadap rata-rata upah rumah tangga dan terhadap rata-rata pendapatan rumah tangga, serta pengaruh terhadap total pendapatan rumah tangga dan terhadap total upah rumah tangga.

Tingkat pendidikan orangtua (kepala rumah tanggga maupun gabungan ayah dan ibu) mempengaruhi secara langsung dan signifikan terhadap rata-rata pendidikan pekerja di rumah tangga dan mempengaruhi secara tidak langsung dan signifikan terhadap pendapatan atau upah rumah tangga di Indonesia.

Pengaruh pendidikan terhadap pendapatan atau upah, pengaruh pengalaman terhadap pendapatan atau upah, dan pengaruh pendidikan orang tua dan kepala rumah tangga terhadap pendidikan pekerja di rumah tangga adalah berpengaruh signifikan. Adapun pengaruh jumlah anak kandung terhadap pendidikan pekerja di rumah tangga tidak berpengaruh signifikan karena tidak terbukti secara signifikan bahwa jumlah anak kandung mempengaruhi secara langsung terhadap rata-rata pendidikan pekerja di rumah tangga maupun mempengaruhi secara tidak langsung terhadap pendapatan atau upah dari rumah tangga tersebut di Indonesia.

\section{Saran}

Bersadarkan simpulan di atas, disarankan kepada para pengambil kebijakan (pemerintah maupun swasta), diantaranya dengan mendorong peningkatan tingkat pendidikan dan pelatihan bagi calon pekerja maupun yang sudah bekerja, karena terbukti tingkat pendidikan pekerja berperan penting dalam peningkatan pendapatan rumah tangga.

Perlu upaya untuk meningkatkan tingkat pendidikan calon kepala rumah tangga maupun kepala rumah yang sudah berkeluarga karena terbukti berperan langsung terhadap peningkatan pendidikan pekerja di keluarga, dan berperan secara tidak langsung terhadap pendapatan rumah tangga.

Penelitian ini memiliki keterbatasan karena mengukur perilaku rumah tangga hanya pada kurun waktu tahun 2000 sampai tahun 2007. Untuk itu perlu dilakukan penelitian lebih lanjut dengan menggunakan rentang waktu yang lebih panjang, atau sampai periode waktu yang terbaru. Penelitian ini dilakukan dengan menggunakan data akhir tahun 2007 karena tahun tersebut merupakan survey IFLS yang terakhir pada saat penelitian ini dilakukan.

\section{DAFTAR PUSTAKA}

Becker, G. 1964. Human Capital: A Theoretical and Empirical Analysis, with Special Reference to Education. $2^{\text {nd }}$ ed. National Bureau of Economic Research (NBER). New York.

Blau, M. D., J. R. Behrman, dan B. L. Wolfe. 1988. Schooling and Earnings Distributions with Endogenous Labour Force Participation, Marital Status and Family Size. Economica, New Series 55(219): 297-316.

Chevalier, A. 2004. Parental Education and Child's Education: A Natural Experiment. Journal of Economic Literature 84(14): 94-112.

Creamer, D. 1961. Some Determinants of Low Family Income. Economic Development and Cultural Change, Essays in the Quantitative Study of Economic Growth, Presented to Simon Kuznets on the Occasion of His Sixtieth Birthday 9(3): 41.

Ding, S., D. Xiao-Yuan dan, S. Li. 2009. Women's Employment and Family Income Inequality During China's Economic Transition. Feminist Economics 15(3): 163-190.

Fafchamps, M. Dan, A. R. Quisumbing. 1999. Human Capital, Productivity, and Labor Allocation in Rural Pakistan. The Journal of Human Resources 34(2): 369406.

Fitzsimona, E. 2007. The Effect of Risk on Education in Indonesia. The University of Chicago.

Greif, A. 2006. Family Structure, Institutions, and Growth: The Origins and Implications of Western Corporations. 
The American Economic Review 96(2): 308-312.

Gundersen, C. dan J. P. Ziliak. 2004. Poverty and Macroeconomic Performance Across Space, Race, and Family Structure. Demography 41(1): 61-86.

Jalan, J. dan M. Ravallion. 2002. Geographic Poverty Traps? A Micro Model of Consumption Growth in Rural China. Journal of Applied Econometrics 17(4): 329-346.

Jungmin, L. 2004. Sibling Size and Investment in Children's Education: An Asian Instrument. Journal of Population Economic 21(4): 855-875.

Mincer, J. 1974. Schoolling, Experience and Earnings. National Bureau of Economic Research. New York.

Purnastuti, L., P. Miller, dan R. Salim. 2011. Economic Returns to Schooling in A Less Developed Country: Evidence For Indonesia. Journal of Economic Literature
International Conference on Applied Economics 28(4).

Ravallion, M. dan Q. Wodon. 2000. Does Child Labour Displace Schooling? Evidence on Behavioural Responses to an Enrollment Subsidy. The Economic Journal 110(462): 158-175.

Roope, U. 1999. Essays in Economics of Education. Dissertation. Economics Kansantaloustieteen Laitoksen Tutkimuksia. Finland.

UNDP. 2012. Human Development Report (HDR) 2011. New York.

Xin, M. dan H. Wu. 1998. Household Income Determination and Regional Income Differential in Rural China. Asian Economic Journal 112(1): 65-88.

Woolridge, M. J. 2009. Introductory Econometrics: A Modern Approach, $4^{\text {th }}$ edition. South Western Cengage Learning. United States. 
Lampiran:

Tabel 7

Spesifikasi Variabel dan Sumber Data

\begin{tabular}{|c|c|c|c|}
\hline Variabel & Keterangan & Komponen & Sumber \\
\hline HI & $\begin{array}{l}\text { Total pendapatan } \\
\text { rumah tangga } \\
\text { (Household Income) } \\
\text { (Rupiah) }\end{array}$ & $\begin{array}{l}\text { Pendapatan upah (Wage) dari } \\
\text { pekerja di rumah tangga usia 10-75 } \\
\text { tahun+ Pendapatan bersih sektor } \\
\text { pertanian (Agr)+Pendapatan } \\
\text { bersih sektor Non-pertanian } \\
\text { (NonAgr) }\end{array}$ & $\begin{array}{l}\text { IFLS hh, Buku } \\
\text { K= ar15b, } \\
\text { ar15a, ar09, } \\
\text { Buku 2= ut09, } \\
\text { nt09 }\end{array}$ \\
\hline HI_mean & $\begin{array}{l}\text { HI rata-rata } \\
\text { (Rupiah) }\end{array}$ & $\begin{array}{l}\text { Pendapatan rata-rata di rumah } \\
\text { tangga tersebut (Total: pekerja usia } \\
10-75)\end{array}$ & \\
\hline Wage & $\begin{array}{l}\text { Total Upah di } \\
\text { Rumah tangga } \\
\text { (Wage) (Rupiah) }\end{array}$ & $\begin{array}{l}\text { Pendapatan upah dari pekerja di } \\
\text { rumah tangga usia 10-75 tahun }\end{array}$ & $\begin{array}{l}\text { IFLS hh, Buku } \\
\mathrm{K}=\text { ar15b, } \\
\text { ar15a, ar09. }\end{array}$ \\
\hline Wage_mean & $\begin{array}{l}\text { Upah rata-rata } \\
\text { (Rupiah) }\end{array}$ & $\begin{array}{l}\text { Upah rata-rata dari pekerja di } \\
\text { rumah tangga }\end{array}$ & \\
\hline Time & $\begin{array}{l}\text { Dummmy waktu } \\
\text { survey }\end{array}$ & $\begin{array}{l}D=1 \text { untuk tahun akhir (2007) dan } \\
D=0 \text { untuk waktu awal (2000) }\end{array}$ & \\
\hline Educ & $\begin{array}{l}\text { Total pendidikan } \\
\text { (Education) (tahun) }\end{array}$ & $\begin{array}{l}\text { Lama pendidikan yang ditempuh } \\
\text { oleh pekerja di rumah tangga }\end{array}$ & $\begin{array}{l}\text { IFLS hh, Buku } \\
\mathrm{K}=\text { ar16, ar09, } \\
\text { ar15a }\end{array}$ \\
\hline Educ_mean & $\begin{array}{l}\text { Rata-rata } \\
\text { pendidikan (Tahun) }\end{array}$ & $\begin{array}{l}\text { Rata-rata lama pendidikan dari } \\
\text { pekerja di rumah tangga usia } 10-75\end{array}$ & \\
\hline Exp & $\begin{array}{l}\text { Pengalaman kerja } \\
\text { (Experience) } \\
\text { (Tahun) }\end{array}$ & $\begin{array}{l}\text { Usia pekerja (AgeLab)-7 tahun } \\
\text { sebelum sekolah-lama pendidikan } \\
\text { (Educ) }\end{array}$ & $\begin{array}{l}\text { IFLS hh, Buku } \\
\mathrm{K}=\operatorname{ar} 16, \operatorname{ar} 09, \\
\text { ar15a }\end{array}$ \\
\hline Exp_mean & $\begin{array}{l}\text { Rata-rata } \\
\text { pengalaman kerja } \\
\text { (Tahun) }\end{array}$ & $\begin{array}{l}\text { Rata-rata pengalaman kerja dari } \\
\text { pekerja usia } 10-75 \text { tahun di rumah } \\
\text { tangga }\end{array}$ & \\
\hline AgeLab & $\begin{array}{l}\text { Usia pekerja (Age of } \\
\text { labor) (Tahun) }\end{array}$ & $\begin{array}{l}\text { Usia pekerja di rumah tangga } \\
\text { (rentang } 10-75 \text { tahun) }\end{array}$ & $\begin{array}{l}\text { IFLS hh, Buku } \\
\mathrm{K}=\text { ar09, ar15a }\end{array}$ \\
\hline EducHead & $\begin{array}{l}\text { Pendidkan kepala } \\
\text { rumah tangga } \\
\text { (Education of Head- } \\
\text { family) }\end{array}$ & $\begin{array}{l}\text { Pedidikan kepala rumah tangga } \\
\text { (Ayah/Ibu/lainnya) }\end{array}$ & $\begin{array}{l}\text { IFLS hh, Buku } \\
\mathrm{K}=\text { ar02b, ar16 }\end{array}$ \\
\hline EdParent & $\begin{array}{l}\text { Pendidkan orang } \\
\text { tua } \\
\text { (Education of parent) }\end{array}$ & Total Pendididikan Ayah dan Ibu & $\begin{array}{l}\text { IFLS hh, Buku } \\
\mathrm{K}=\text { ar02b, ar16 }\end{array}$ \\
\hline Sibling & $\begin{array}{l}\text { Jumlah anak } \\
\text { kandung }\end{array}$ & $\begin{array}{l}\text { Total anak kandung pada rumah } \\
\text { tangga tersebut baik yang tinggal } \\
\text { di rumah tangga tsb atau di luar }\end{array}$ & $\begin{array}{l}\text { IFLS hh, Buku } \\
\mathrm{K}=\mathrm{ar02b}, \mathrm{ar} 01 \mathrm{a}\end{array}$ \\
\hline SiblStay & $\begin{array}{l}\text { Jumlah anak } \\
\text { kandung yang } \\
\text { tinggal di rumah } \\
\text { tangga tersebut }\end{array}$ & $\begin{array}{l}\text { Total anak kandung pada rumah } \\
\text { tangga tersebut tidak termasuk } \\
\text { tinggal di luar rumah tangga } \\
\text { tersebut }\end{array}$ & $\begin{array}{l}\text { IFLS hh, Buku } \\
\mathrm{K}=\operatorname{ar} 02 \mathrm{~b}, \operatorname{ar} 01 \mathrm{a}\end{array}$ \\
\hline
\end{tabular}

Sumber : Buku kuesioner IFLS (diolah kembali oleh penulis) 